Limnol. Rev. (2015) 15, 4: 155-163

\title{
Water quality assessment in a shallow lake used for tourism
}

\author{
Ewa A. Dembowska, Patrycja L. Pul
}

\begin{abstract}
Department of Hydrobiology, Faculty of Biology and Environmental Protection, Nicolaus Copernicus University, Lwowska 1,87-100 Toruń, Poland, e-mail dembow@umk.pl (corresponding author)
\end{abstract}

\begin{abstract}
The routine evaluation of water quality is limited to lakes with the largest area. In Poland, only lakes with an area exceeding 50 hectares are monitored by the State Environmental Monitoring System. For many local communities, however, small lakes are more important. This applies mainly to areas with a small number of lakes, where even the smallest lakes are used for various purposes. This paper presents the results of phytoplankton analysis in a small and shallow lake used for recreation. The study was conducted at three sites located in different parts of the lake. A total of 122 algae taxa were identified in the phytoplankton, mainly diatoms and green algae. The most constant taxa in the lake were: Stephanodiscus hantzschii, Desmodesmus communis, Pediastrum tetras and Crucigenia tetrapedia. The average phytoplankton biomass was $37 \mathrm{mg} \mathrm{l}^{-1}$. The maximum biomass, almost $140 \mathrm{mg} \mathrm{dm}^{-3}$, was recorded in late July at the site located near the beach. At that time, there was a massive cyanobacterial bloom composed of Microcystis wesenbergii and Aphanizomenon issatschenkoi. Based on these studies, the lake should be classified as hypertrophic with bad ecological status. This lake should not be used for recreational purposes in the current state.
\end{abstract}

Key words: phytoplankton, abundance, biomass, hypertrophy, cyanobacterial bloom

\section{Introduction}

According to the latest legal regulations in Poland, a standard assessment of water quality includes lakes with an area exceeding 50 hectares. Such water bodies, however, represent only $15 \%$ of all natural lakes in Poland (Jańczak 1996). In practice, this means that the majority of lakes are small, ranging in size from 1 to 50 ha. Therefore, there is an urgent necessity to assess such small lakes. Their bad condition may be dangerous to human health. The studied lake, which is used for recreation, is one of such small and shallow water bodies.

Shallow lakes are very numerous all around the world. They are definitely more frequent than deep lakes (Padisák and Reynolds 2003). In shallow lakes, the maximum depth does not usually exceed $6 \mathrm{~m}$, and the average is $3 \mathrm{~m}$. These lakes can be regarded as water bodies consisting entirely of the littoral zone where light reaches the bottom and enables the macrophytes to develop over the entire surface of the bottom.

Shallow lakes have varied light conditions and heterogeneous vegetation of vascular plants. There- fore, there are two different categories of shallow lakes: clear-water lakes, where dense macrophyte vegetation covers the bottom, and turbid-water lakes, which are dominated by planktonic organisms. Restricted access of light to the bottom reduces the development of macrophytes (e.g. Scheffer and Jeppesen 1998). Dokulil and Teubner (2003) argue that, in contrast to deep lakes, many shallow lakes may rapidly change from a clear-water state dominated by macrophytes to a turbid-water state dominated by phytoplankton.

Shallow lakes are of major importance, especially in areas dominated by this type of water body. They have many various functions, such as for tourism, recreation, irrigation of agricultural areas and as a drinking water supply. Assessment of the trophic and ecological state allows the appropriate use of lakes as an economic resource. The aim of this study was to assess the trophic and ecological status of a shallow lake used for recreational purposes. Phytoplankton species composition, abundance and biomass were used in this assessment as indicators of water quality. 


\section{Study area}

Lake Ostrowąs is located in northern Poland in the Wielkopolska Lakeland, in the catchment area of the River Tążyna (Fig.1). It is one of the few lakes on the Inowrockaw Plains. The lake has an area of 30.7 hectares. The total volume amounts to 644.7 thousand $\mathrm{m}^{3}$. Its maximum depth is $3.7 \mathrm{~m}$, and the mean depth, $2.1 \mathrm{~m}$ (Table 1). The total catchment area of the lake covers $8.6 \mathrm{~km}^{2}$. The catchment area is dominated by agriculture, mainly arable lands. The lake is supplied by small temporary streams. The quality of water flowing into the lake indicates a strong influence of pollution from agricultural sources. In terms of fishing, the lake is classified as a rope-pike type. Analysis of morphometric features, and of the hydrographic basin of Lake Ostrowąs indicate a very high predisposition to degradation (WIOŚ 2005). Now the lake is mainly used for recreational purposes. It is possible to rent cottages and swimming equipment; an artificial beach was created.
Table 1. Morphometric, physicochemical and biological data of Lake Ostrowąs

\begin{tabular}{|c|c|}
\hline Longitude & $52^{\circ} 49^{\prime} 45^{\prime \prime} \mathrm{N}$ \\
\hline Latitude & $18^{\circ} 42^{\prime} 10^{\prime \prime E}$ \\
\hline Surface [ha] & 30.7 \\
\hline Maximum depth [m] & 3.7 \\
\hline Maximum length [m] & 995 \\
\hline Maximum width [m] & 485 \\
\hline Secchi Depth [m] ${ }^{*}$ & 0.7 \\
\hline $\mathrm{pH}^{*}$ & 8.5 \\
\hline $\mathrm{EC}\left[\mu \mathrm{S} \mathrm{cm}{ }^{-1}\right]^{*}$ & 780 \\
\hline $\mathrm{TP}\left[\mathrm{mg} \mathrm{dm}^{-3}\right]^{*}$ & 0.08 \\
\hline $\mathrm{TN}\left[\mathrm{mg} \mathrm{dm}^{-3}\right]^{*}$ & 2.66 \\
\hline $\mathrm{Chl} a\left[\mu \mathrm{g} \mathrm{dm}^{-3}\right]^{*}$ & 37.4 \\
\hline Trophic State Index (TSI $\left.\left.\right|_{\mathrm{SD}+\mathrm{TP}+\mathrm{TP}+\mathrm{Chla}}\right)$ & 64.23 \\
\hline Phytoplankton abundance $\left[10^{6}\right.$ ind. $\left.\mathrm{dm}^{-3}\right]$ & 53.6 \\
\hline Phytoplankton biomass [mg dm ${ }^{-3}$ ] & 37.5 \\
\hline
\end{tabular}

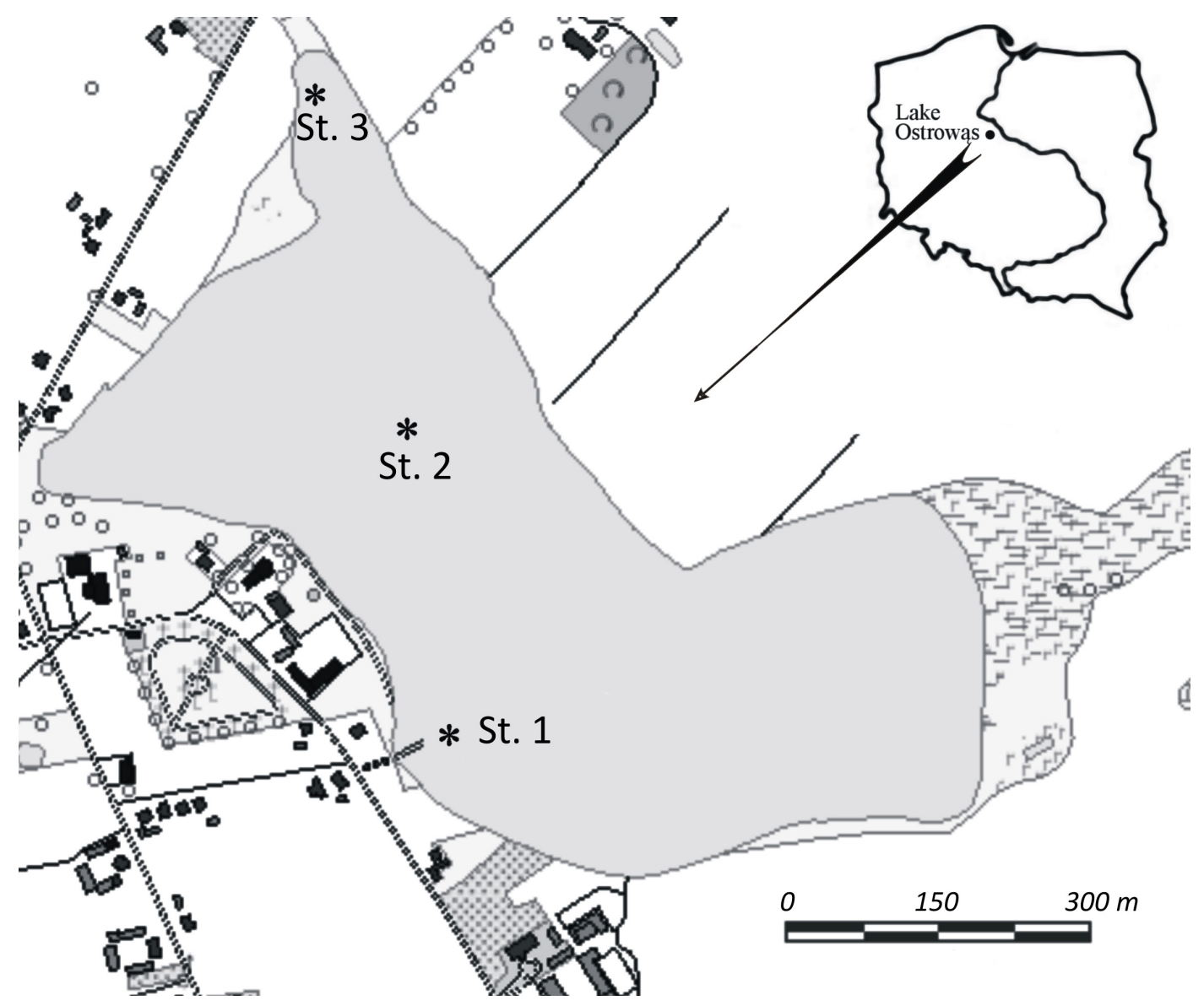

Fig. 1. Map of Lake Ostrowąs with sampling sites 


\section{Methods}

Material for the study of phytoplankton was collected from three sites (Fig. 1) of the following locations: the beach at the southern shore of the lake (St. 1), the deepest point of the lake (St. 2) and the north shore of the lake dominated by vascular plants (St. 3). Samples were collected twice a month from June to September 2014, and once a month in January and May 2015. A total of 27 samples of phytoplankton were examined at nine different dates.

Qualitative samples were collected using a plankton net with $25 \mu \mathrm{m}$ mesh diameter from the euphotic zone and preserved in $4 \%$ formalin. Identification of phytoplankton was performed with the use of a light microscope Nikon Alphaphot YS2. Determination of diatoms was based on cell wall structure at $\times 1000$ magnification, after cleaning them off the organic content. In order to obtain the pure frustules, concentrated nitric and sulphuric acids, and 30\% hydrogen peroxide were applied. For preparation, a synthetic resin having a high refractive index - Naphrax - was used. Non-concentrated samples were collected for quantitative analyses from beneath the surface, i.e. at a depth of ca. $0.5 \mathrm{~m}$. Quantitative phytoplankton samples were fixed with $1 \%$ acidified Lugol's iodine (J in $\mathrm{KJ})$. The counts of phytoplankton were carried out to the species level whenever possible, using an inverted microscope (MOD-2 PZO) following the Utermöhl (1958) technique at $\times 400$ magnification in chambers of $2 \mathrm{~cm}^{3}$ after at least $24 \mathrm{~h}$ sedimentation. Biovolumes of all algal species were calculated using the volumetric method by Hillebrand et al. (1999) and Sun and Liu (2003) and assuming that $1 \mathrm{~mm}^{3}$ of algae is equal to 1 $\mathrm{mg}$ (Elser and Carpenter 1988). The biovolume is presented as biomass (wet weight) per litre $\left(\mathrm{B}, \mathrm{mg} \mathrm{dm}^{-3}\right)$.

The dominant species described in this paper (with the biomass of more than 10\%) were classified into functional groups (FG) based on the studies by Kruk et al. (2002), Reynolds et al. (2002), Reynolds (2006) and Padisák et al. (2009). Functional groups of phytoplankton illustrate the characteristics of the environment more effectively (e.g. water mixing, trophic level, nutrient deficiency) than single species.

The evaluation of the aquatic environment based on the species composition of a diatom community was prepared using a list of indicator species by Van Dam et al. (1994). Diatom species were classified according to their trophic requirements, tolerance to contamination, preference for $\mathrm{pH}$ and oxygen demand. The trophic level of the lake was assessed on the basis of the species composition using Nygaard's Trophic State Index (Hutchinson 1967, after Nygaard 1949). It classified lakes with ratios of the number of taxa of major algae groups of less than 1.0 as oligotrophic, while those with ratios of more than 3.0 as eutrophic. Based on the biomass of phytoplankton and biomass of blue-green algae, two metrics were calculated, out of the three included in the Phytoplankton Multimetric for Polish Lakes (used to assess the ecological status of Polish lakes) (Hutorowicz and Pasztaleniec 2014). To assess the similarity between phytoplankton species composition (Jaccard's coefficient - J) and species diversity (Shannon-Wiener - $\mathrm{H}^{\prime}$ evenness - e), a multivariate statistical package was used - MVSP 3.2 (Kovach 2010).

\section{Results}

\section{Taxonomic composition}

A total of 122 taxa were identified in Lake Ostrowąs and half of them (61) belonged to Bacillariophyceae. The remaining taxa were Chlorophyta (40 taxa), Cyanobacteria (15), Euglenophyta (5) and 1 taxon of Chrysophyceae.

The greatest taxonomic richness was at site 1, where 106 species were recorded. The smallest number of species, only 98 , was found at site 2 , located in the central part of the lake. Only 4 species of phytoplankton were recorded for each sample: Stephanodiscus hantzschii Grunow, Desmodesmus communis E.Hegewald, Pediastrum tetras (Ehrenberg) Ralfs and Crucigenia tetrapedia (Kirchner) Kuntze. Phytoplankton was represented by e.g. Fragilaria reicheltii, which is a threatened species in Poland. Taxa that represented more than $10 \%$ of the total biomass were members of 8 FGs (Table 2); however, M (Microcystis), H1 (Anabaena spiroides Klebahn, Aphanizomenon issatschenkoi) and J (many coccal green algae) were the main FGs.

\section{Quantitative analysis of phytoplankton}

The average phytoplankton abundance in Lake Ostrowąs throughout the study period was $53.61410^{6}$ ind. $\mathrm{dm}^{-3}$. The abundance showed significant spatial differences (Fig. 2). The average phytoplankton abundance was the highest at site 1, i.e. $61.86310^{6}$ ind. $\mathrm{dm}^{-3}$. The lowest number of $46.78710^{6} \mathrm{ind} . \mathrm{dm}^{-3}$ was recorded at site 3. Algal abundance ranged from the minimum of $13.09810^{6}$ ind. $\mathrm{dm}^{-3}$ in January 2015 at site 2, to the maximum of $167.50310^{6}$ ind. dm ${ }^{-3}$ in July 2014 at site 1. 
Table 2. Dominant algae species and values of the total biomass ( $\mathrm{B}$, in $\left.\mathrm{mg} \mathrm{dm}^{-3}\right)$ in phytoplankton of Lake Ostrowąs

\begin{tabular}{|c|c|c|c|c|c|c|c|c|c|}
\hline \multirow{2}{*}{ Date } & \multicolumn{3}{|l|}{ Site 1} & \multicolumn{3}{|l|}{ Site 2} & \multicolumn{3}{|l|}{ Site 3} \\
\hline & $B$ & Dominant taxon & $\% \quad F G$ & $\mathrm{~B}$ & Dominant taxon & $\% \quad F G$ & $\mathrm{~B}$ & Dominant taxon & $\% \mathrm{FG}$ \\
\hline 15.06 .14 & 10.230 & $\begin{array}{l}\text { Tetraëdron minimum } \\
\text { (A.Braun) Hansgirg } \\
\text { Anabaena spiroides } \\
\text { Aphanizomenon } \\
\text { issatschenkoi } \\
\text { Cosmarium punctulatum } \\
\text { Brébisson }\end{array}$ & $\begin{array}{l}19 \mathrm{~J} \\
16 \mathrm{H} 1 \\
12 \mathrm{H} 1 \\
11 \mathrm{~N}\end{array}$ & 8.568 & $\begin{array}{l}\text { Microcystis } \\
\text { aeruginosa } \\
\text { Anabaena spiroides }\end{array}$ & $\begin{array}{ll}21 & M \\
17 \mathrm{H} 1\end{array}$ & 6.638 & $\begin{array}{l}\text { Microcystis aeruginosa } \\
\text { Aphanizomenon } \\
\text { issatschenkoi }\end{array}$ & $\begin{array}{l}24 \mathrm{M} \\
16 \mathrm{H} 1\end{array}$ \\
\hline 30.06 .14 & 13.109 & $\begin{array}{l}\text { Microcystis aeruginosa } \\
\text { Kützing } \\
\text { Microcystis wesenbergii } \\
\text { Komárek }\end{array}$ & $\begin{array}{l}30 \mathrm{M} \\
30 \mathrm{M}\end{array}$ & 7.762 & $\begin{array}{l}\text { Microcystis } \\
\text { wesenbergii } \\
\text { Aphanizomenon } \\
\text { issatschenkoi }\end{array}$ & $\begin{array}{l}26 \mathrm{M} \\
12 \mathrm{H} 1\end{array}$ & 4.770 & $\begin{array}{l}\text { Microcystis } \\
\text { wesenbergii }\end{array}$ & $48 \mathrm{M}$ \\
\hline 15.07 .14 & 72.274 & Microcystis wesenbergii & $88 \mathrm{M}$ & 71.602 & $\begin{array}{l}\text { Microcystis } \\
\text { wesenbergii }\end{array}$ & $88 \mathrm{M}$ & 91.296 & $\begin{array}{l}\text { Microcystis } \\
\text { wesenbergii }\end{array}$ & $89 M$ \\
\hline 30.07 .14 & 137.205 & $\begin{array}{l}\text { Microcystis wesenbergii } \\
\text { Aphanizomenon } \\
\text { issatschenkoi }\end{array}$ & $\begin{array}{l}69 \mathrm{M} \\
20 \mathrm{H} 1\end{array}$ & 130.326 & $\begin{array}{l}\text { Microcystis } \\
\text { wesenbergii } \\
\text { Aphanizomenon } \\
\text { issatschenkoi }\end{array}$ & $\begin{array}{l}71 \mathrm{M} \\
24 \mathrm{H} 1\end{array}$ & 90.279 & $\begin{array}{l}\text { Microcystis } \\
\text { wesenbergii } \\
\text { Aphanizomenon } \\
\text { issatschenkoi }\end{array}$ & $\begin{array}{l}65 \mathrm{M} \\
28 \mathrm{H} 1\end{array}$ \\
\hline 15.08 .14 & 21.181 & $\begin{array}{l}\text { Microcystis wesenbergii } \\
\text { Aphanizomenon } \\
\text { issatschenkoi }\end{array}$ & $\begin{array}{l}47 \mathrm{M} \\
27 \mathrm{H} 1\end{array}$ & 41.783 & $\begin{array}{l}\text { Microcystis } \\
\text { wesenbergii } \\
\text { Aphanizomenon } \\
\text { issatschenkoi }\end{array}$ & $\begin{array}{l}70 \mathrm{M} \\
15 \mathrm{H} 1\end{array}$ & 86.102 & $\begin{array}{l}\text { Microcystis } \\
\text { wesenbergii }\end{array}$ & $86 \mathrm{M}$ \\
\hline 15.09 .14 & 16.221 & $\begin{array}{l}\text { Microcystis wesenbergii } \\
\text { Snowella sp. }\end{array}$ & $\begin{array}{l}50 \mathrm{M} \\
13 \mathrm{Lo}\end{array}$ & 47.377 & $\begin{array}{l}\text { Microcystis } \\
\text { wesenbergii }\end{array}$ & $77 \mathrm{M}$ & 19.216 & $\begin{array}{l}\text { Microcystis } \\
\text { wesenbergii } \\
\text { Crucigenia tetrapedia }\end{array}$ & $\begin{array}{l}48 \mathrm{M} \\
10 \mathrm{~J}\end{array}$ \\
\hline 30.09 .14 & 35.495 & $\begin{array}{l}\text { Cymatopleura solea } \\
\text { (Brébisson) W.Smith } \\
\text { Gonatozygon sp. } \\
\text { Cosmarium punctulatum }\end{array}$ & $\begin{array}{l}38 \\
26 \\
23 \mathrm{~N}\end{array}$ & 3.002 & Gonatozygon sp. & 79 & 15.711 & $\begin{array}{l}\text { Cosmarium } \\
\text { punctulatum } \\
\text { Fragilaria ulna (Nitzsch) } \\
\text { Lange-Bertalot } \\
\text { Coelastrum } \\
\text { astroideum De Notaris }\end{array}$ & $\begin{array}{l}47 \mathrm{~N} \\
19 \mathrm{D} \\
11 \mathrm{~J}\end{array}$ \\
\hline 15.01 .15 & 19.580 & $\begin{array}{l}\text { Asterionella formosa } \\
\text { Hassall }\end{array}$ & $79 \mathrm{C}$ & 4.858 & Asterionella formosa & $51 \mathrm{C}$ & 6.599 & $\begin{array}{l}\text { Asterionella formosa } \\
\text { Oocystis } \\
\text { solitaria Wittrock }\end{array}$ & $\begin{array}{l}55 \mathrm{C} \\
13 \mathrm{~F}\end{array}$ \\
\hline 15.05 .15 & 5.299 & $\begin{array}{l}\text { Tetraëdron minimum } \\
\text { Pediastrum tetras } \\
\text { Pediastrum duplex Meyen }\end{array}$ & $\begin{array}{l}28 \mathrm{~J} \\
14 \mathrm{~J} \\
13 \mathrm{~J}\end{array}$ & 4.779 & $\begin{array}{l}\text { Pediastrum duplex } \\
\text { Pediastrum tetras }\end{array}$ & $\begin{array}{l}14 \mathrm{~J} \\
10 \mathrm{~J}\end{array}$ & 5.855 & $\begin{array}{l}\text { Snowella sp. } \\
\text { Pediastrum tetras } \\
\text { Tetraëdron minimum }\end{array}$ & $\begin{array}{l}12 \mathrm{Lo} \\
17 \mathrm{~J} \\
25 \mathrm{~J}\end{array}$ \\
\hline
\end{tabular}

The average phytoplankton biomass in the lake was $37.5 \mathrm{mg} \mathrm{dm}^{-3}$. The maximum biomass (137.2 $\mathrm{mg} \mathrm{dm}^{-3}$ ) was detected in July 2014 at site 1 (Fig. 3), and the lowest $\left(4.8 \mathrm{mg} \mathrm{dm}^{-3}\right)$ in June 2014 at site 3 . In warm seasons, the phytoplankton biomass was composed of Cyanobacteria and Chlorophyta. The dominant blue-green algae in Lake Ostrowąs were as follows: Microcystis aeruginosa, Microcystis wesenbergii, Aphanizomenon issatschenkoi and Snowella sp. In spring and autumn, Chlorococcales dominated in the biomass, while in the winter the biomass was formed by diatoms, mainly Asterionella formosa (Table 2).
The ratio of biomass and abundance $(\mathrm{B} / \mathrm{N})$ indicates that small-size species dominated in phytoplankton in the spring (May, June) (Fig. 4). The maximum dimensions were recorded in July, when the phytoplankton was dominated by colonial cyanobacteria Microcystis.

Jaccard's similarity analysis allowed groups of phytoplankton to be isolated in different seasons (Fig. 5). The greatest similarity of phytoplankton was recorded in summer (June, July, August), the second highest, in winter (January). The most diverse phytoplankton was in spring and autumn (May, September). 


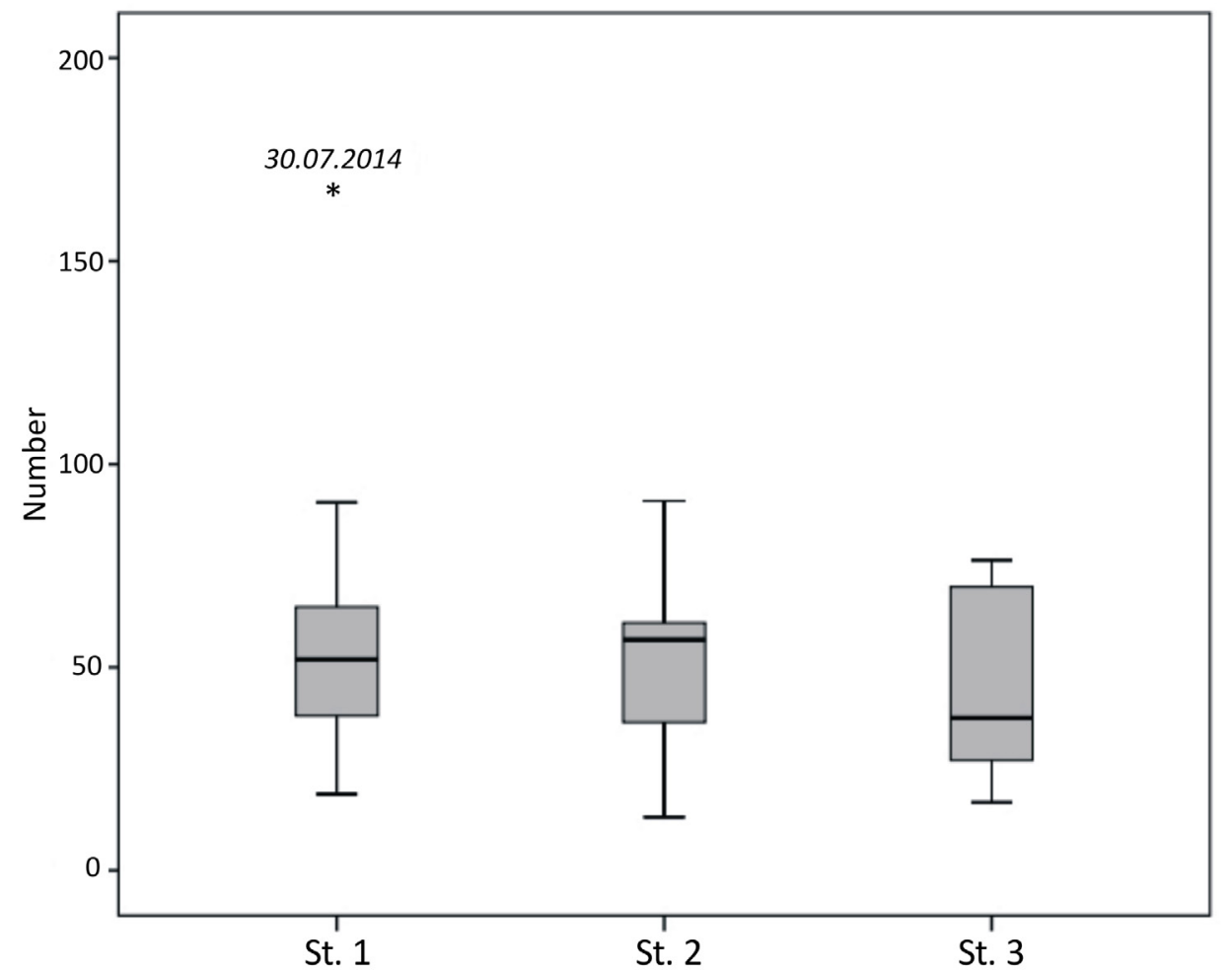

Fig. 2. Spatial differences in the number $\left(10^{6} \mathrm{ind} . \mathrm{dm}^{-3}\right)$ of phytoplankton (median, range and standard deviation) in Lake Ostrowąs

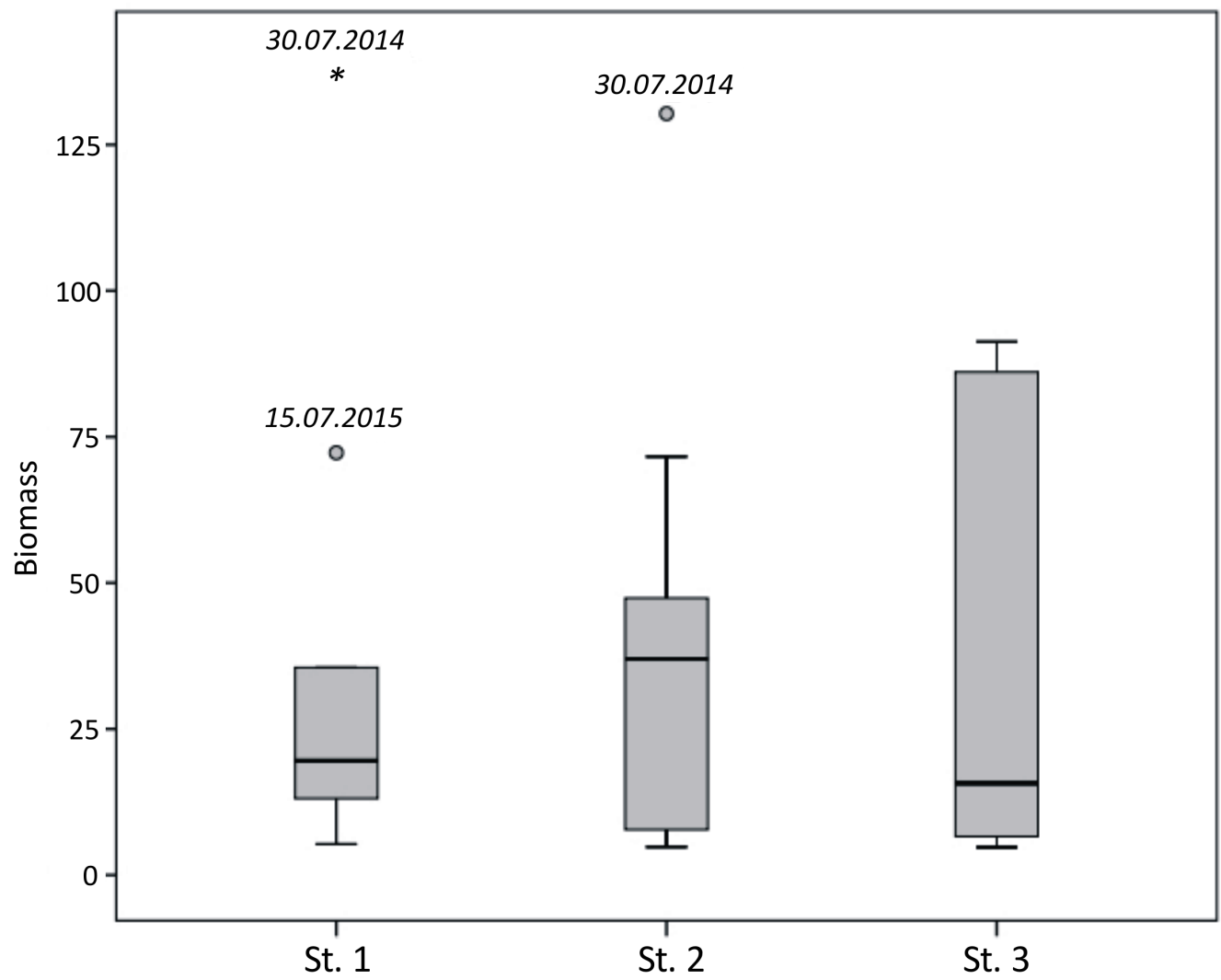

Fig. 3. Spatial differences in the biomass $\left(\mathrm{mg} \mathrm{dm}^{-3}\right)$ of phytoplankton (median, range and standard deviation) in Lake Ostrowąs 


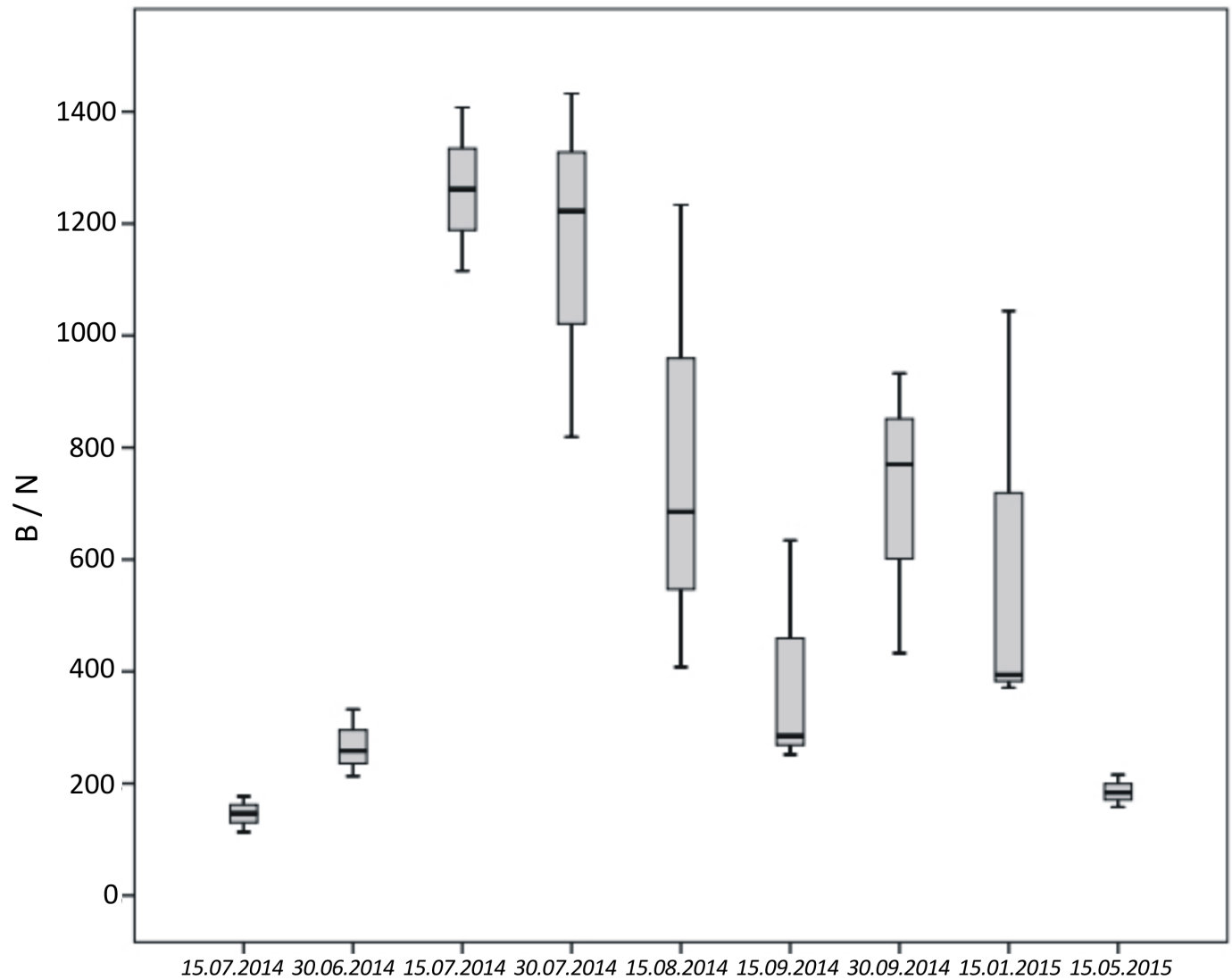

Fig. 4. Temporal fluctuations of "average cell biovolume" $\left(\mu \mathrm{m}^{3}\right)$ in Lake Ostrowąs

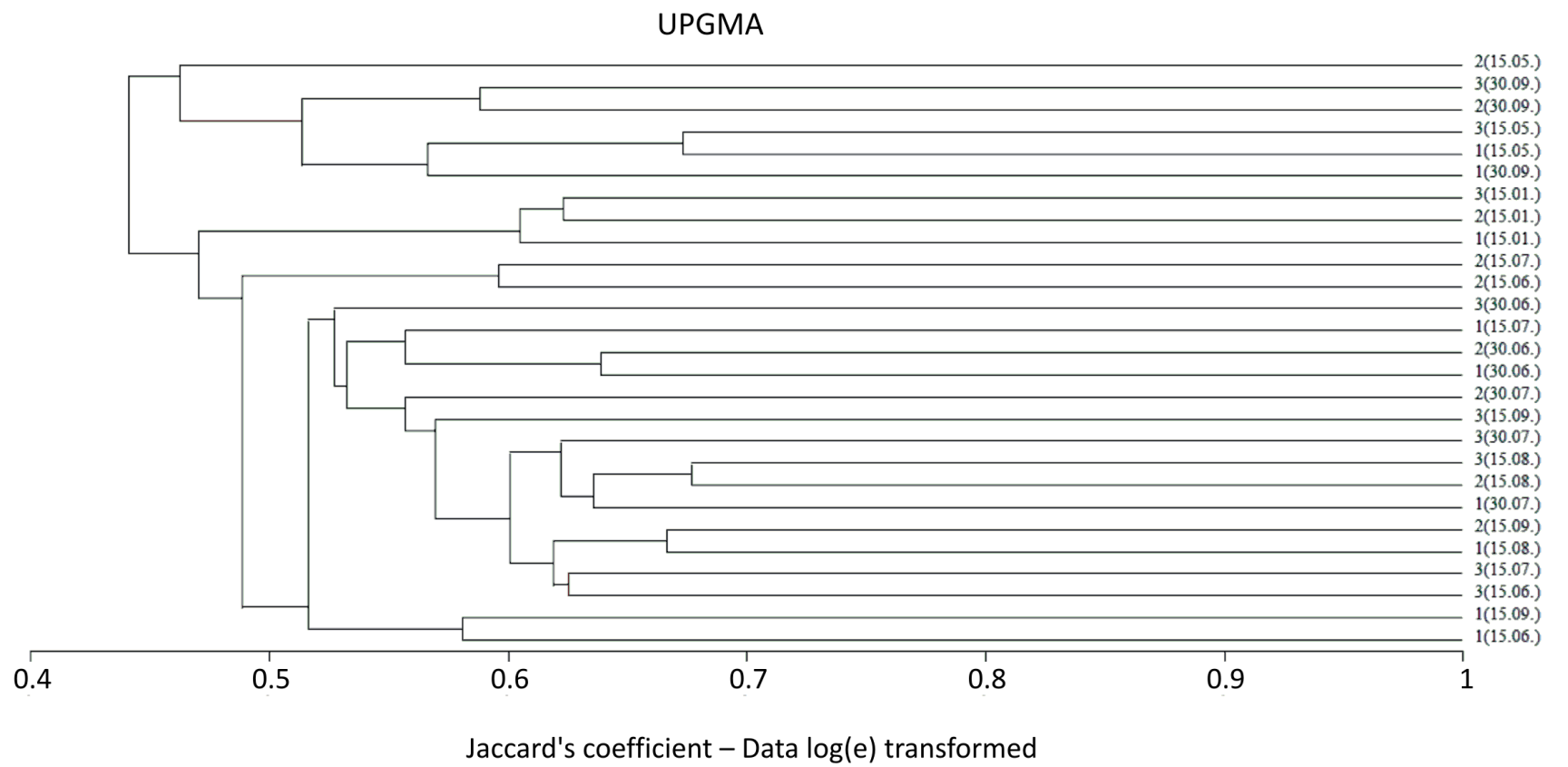

Fig. 5. Cluster analysis of phytoplankton similarity based on species composition (Jaccard's coefficient) in Lake Ostrowąs 
Shannon's species diversity (Table 3 ) had a small value $\approx 1(0.70-1.16)$. Similarly, the evenness (e), the average value of which was 0.53 , indicated a strong dominance of a few species.

Table 3. Values of phytoplankton species diversity indices $\left(\mathrm{H}^{\prime}-\right.$ Shannon-Wiener index; e - evenness; $\mathrm{S}$ - the number of species) in Ostrowąs Lake

\begin{tabular}{|c|c|c|c|c|}
\hline Date & Site & $\mathrm{H}^{\prime}$ & $\mathrm{e}$ & $\mathrm{S}$ \\
\hline & 1 & 0.821 & 0.453 & 65 \\
\hline \multirow[t]{2}{*}{15.06 .2014} & 2 & 0.717 & 0.448 & 40 \\
\hline & 3 & 0.863 & 0.501 & 53 \\
\hline \multirow{3}{*}{30.06 .2014} & 1 & 0.866 & 0.489 & 59 \\
\hline & 2 & 0.832 & 0.470 & 59 \\
\hline & 3 & 0.826 & 0.469 & 58 \\
\hline \multirow{3}{*}{15.07 .2014} & 1 & 0.860 & 0.490 & 57 \\
\hline & 2 & 0.859 & 0,557 & 35 \\
\hline & 3 & 0.837 & 0.490 & 51 \\
\hline \multirow{3}{*}{30.07 .2014} & 1 & 0.712 & 0.387 & 69 \\
\hline & 2 & 0.895 & 0.541 & 45 \\
\hline & 3 & 0.975 & 0.553 & 58 \\
\hline \multirow{3}{*}{15.08 .2014} & 1 & 1.046 & 0.622 & 48 \\
\hline & 2 & 1.110 & 0.632 & 57 \\
\hline & 3 & 1.014 & 0.591 & 52 \\
\hline \multirow{3}{*}{15.09 .2014} & 1 & 0.805 & 0.469 & 52 \\
\hline & 2 & 0.973 & 0.567 & 52 \\
\hline & 3 & 0.898 & 0.546 & 44 \\
\hline \multirow{3}{*}{30.09 .2014} & 1 & 0.797 & 0.482 & 45 \\
\hline & 2 & 0.695 & 0.431 & 41 \\
\hline & 3 & 0.861 & 0.537 & 40 \\
\hline \multirow{3}{*}{15.01 .2015} & 1 & 1.069 & 0.659 & 42 \\
\hline & 2 & 1.162 & 0.695 & 47 \\
\hline & 3 & 1.120 & 0.652 & 52 \\
\hline \multirow{3}{*}{15.05 .2015} & 1 & 0.768 & 0.462 & 46 \\
\hline & 2 & 0.886 & 0.579 & 34 \\
\hline & 3 & 0.740 & 0.459 & 41 \\
\hline
\end{tabular}

Lake water quality assessment

Based on the species composition of phytoplankton, Nygaard's trophic index was calculated, and its value was very high -11.8 .

In the studied lake, 61 taxa of diatoms were identified. Among them, 53 species were used to assess the water quality. In terms of trophic conditions, the largest group were diatoms living in a wide range of fertility (oligo-/eutrophic), and $21 \%$ of species were typical of eutrophic conditions. In terms of tolerance to contamination, tolerant species (31 species - 58\%) were dominant. In Lake Ostrowąs, 30 species with an average oxygen demand (57\%) were recorded. Due to the preference for water $\mathrm{pH}, 39$ alkalibiontic species (74\%) were recorded.

Based on the biomass of phytoplankton and biomass of blue-green algae, two metrics were calcu- lated out of the three included in PMPL. The results at all three sites indicated a very bad ecological status of the studied lake. Calculated metrics reached the maximum (5) value.

\section{Discussion}

According to the classification of the trophic status (Carlson 1977; Carlson and Simpson 1996; Kratzer and Brezonik 1981), Lake Ostrowąs is highly eutrophic (Table 1).

The analysis of plankton taxonomic composition, abundance, and biomass is commonly used to evaluate the trophic and ecological state of water bodies (e.g. van Dam et al. 1994; Hutorowicz and Pasztaleniec 2014; Dembowska et al. 2015).

The phytoplankton species composition was similar at all sites; differences in the number of species between the sites were insignificant. The highest number of species was recorded at site1, near the beach, whereas the lowest was in the northern part of the lake at site 3 located near macrophytes. Based on the species composition, Nygaard's trophic index was calculated (Hutchinson 1967, after Nygaard 1949), and its value - 11.8 - indicated highly trophic conditions. Such a high Nygaard index value was mainly due to a large number of species of coccoid green algae and cyanobacteria.

During the summer season, the number of blue-green algae in Lake Ostrowąs was over $13010^{6}$ ind. $\mathrm{dm}^{-3}$. Dominant blue-green algae (Microcystis wesenbergii, Microcystis aeruginosa, Aphanizomenon issatschenkoi, Anabaena spiroides and Snowella sp.) were characteristic of highly eutrophic waters. Very high values of the phytoplankton biomass (Table 2), ranging from 4.8 to $137 \mathrm{mg} \mathrm{dm}^{-3}$, proved hypertrophic conditions of the lake (Vollenweider and Kerekes 1982), and according to the criteria defined by Bucka (1987), they indicated a constant water bloom. Starting from July, an apparent biomass increase was observed. It was the result of the mass development of cyanobacteria. Cyanobacteria often cause water blooms in shallow, highly eutrophic lakes (Dembowska 2011; Kobos et al. 2013; Dembowska et al. 2015).

Algal blooms lead to excessive production of organic matter. It is dangerous to the rest of the biocoenosis of the lake (Bucka and Wilk-Woźniak 2005). Water blooms (especially cyanobacterial) have a negative impact on the use of water for utility purposes, such as water supply, industrial and recreational ones. 
Blooms of the water are visible as scum on the water surface, and are reflected in low water transparency and occasionally a specific smell (Bucka 1987; Smayda 1997). Some cyanobacteria float on the surface forming a visible scum, because of the presence of gas vesicles. Bucka (1987) listed species capable of creating a water bloom, including e.g. Microcystis, Aphanizomenon and Anabaena. These forms of blue-greens are potential producers of toxins. Toxins can be accumulated in animal bodies; therefore indirectly the problem may also affect humans.

The success of cyanobacteria in shallow lakes is possible due to the high resistance of this group to unfavourable environmental conditions (Reynolds et al. 1987). The occurrence of water bloom is possible due to excessive amounts of nutrients. The ratio N:P in the studied lake was very high, and was over 33 . This high level of N:P is suitable for Chroococcales (e.g. FG $\mathrm{M})$. Nostocales (FG H1) occur less frequently in this lake. For this group of cyanobacteria, the most suitable ratio of $\mathrm{N}: \mathrm{P}$ is low $(<10)$. Nostocales are capable of assimilating the atmospheric nitrogen because of the presence of heterocysts. Microcystis wesenbergii was dominant in the lake, representing about $90 \%$ of the total biomass at all sites in July. Dokulil and Teubner (2000) indicate the optimum molar N:P ratio as 18 for Microcystis wesenbergii.

Beaulieu et al. (2013) reported that water temperature is a significant and independent predictor of cyanobacterial biomass. While nutrient over-enrichment promotes a bloom of cyanobacteria, climate change provides an additional catalyst for their expansion (Paerl and Otten 2013). Global warming may additionally extend the duration of cyanobacterial blooms in lakes. At the end of July 2014, there was a very intensive development of blue-green algae in Lake Ostrowąs (average biomass of $119 \mathrm{mg} \mathrm{dm}^{-3}$ ). According to the Monthly Climate Monitoring Bulletin of the Institute of Meteorology and Water Management (IMGW 2014), this month was extremely warm. While in August 2014 when a normal temperature was reported, a decline in the phytoplankton biomass to $50 \mathrm{mg} \mathrm{dm}^{-3}$ and a decline in cyanobacteria contribution in the whole phytoplankton biomass were observed (Table 2).

In the end, algal blooms disturbed the development of submerged macrophytes, which might compete for nutrients and they could be a refuge for herbivorous zooplankton. The growth of phytoplankton in Lake Ostrowąs was clearly spatially diverse. At the site which was dominated by macrophytes, phytoplankton abundance was smaller than at the other sites. At this site, slightly greater diversity was observed compared to the site near the beach. In the vicinity of macrophytes, 8 FGs dominated (J, H1, F, D, C, Lo, M, N) and near the beach, 6 FGs (J, H1, C, Lo, M, N). However, biodiversity indicators $\left(\mathrm{H}^{\prime}, \mathrm{e}\right)$ at all sites were similar. There were no significant differences between the sites due to the small area, little depth and a high (14.6) rate of exposure. Such morphological conditions of the lake favour the mixing and thus homogenization of plankton.

Because of the lake's location in an area with a small number of lakes, the water body serves an important recreational function. For this reason, it is necessary to improve the quality of water. The ecological status assessment based on the biomass of cyanobacteria and the total phytoplankton biomass indicated the worst state. The lake is ecologically significantly degraded and requires immediate restoration. This objective is usually achieved through treatments, which lead to a reduction in or the elimination of algal blooms. Reduction in the dominance of phytoplankton blooms in lakes is always associated with a reduction in the load of nutrients from the catchment. However, it is difficult to predict whether the restoration of this water body will bring the expected and long-term effects, because the lake is surrounded by an agricultural area.

In conclusion, a routine evaluation of the water quality should include not only the largest lakes, but also the smaller ones, especially those of particular importance. Such a lake was studied. The problem of water quality in lakes is especially important in areas with a small number of lakes, e.g. the Inowrocław Plains. The recreational use of water bodies in summer requires the continuous monitoring of the water quality. Not only the surface area but also how the lake is used should be taken into account during the evaluation of water quality.

\section{References}

Beaulieu M., Pick F., Gregory-Eaves I., 2013, Nutrients and water temperature are significant predictors of cyanobacterial biomass in a 1147 lakes data set, Limnol. Oceanogr. 58(5): 1736-1746.

Bucka H., 1987, Ecological aspects of the mass appearance of planktonic algae in the dam reservoirs of southern Poland, Acta Hydrobiol. 29(2): 149-191. 
Bucka H., Wilk-Woźniak E., 2005, A contribution to the knowledge of some potentially toxic cyanobacteria species forming blooms in water bodies - chosen examples, Oceanol. Hydrobiol. Studies 34 (Suppl. 3): 43-53.

Carlson R.E., 1977, A Trophic State Index for Lakes, Limnol. Oceanogr 22(2): 361-369.

Carlson R.E., Simpson J., 1996, Coordinator's Guide to Volunteer Lake Monitoring Methods, North American Lake Management Society, pp. 96. Retrived from: http:// dipin.kent.edu/tsi.html.

Dembowska E., 2011, Cyanobacterial blooms in shallow lakes of the Iławskie Lakes District, Limnol. Rev. 11(2): 69-79.

Dembowska E., Napiórkowski P., Mieszczankin T., Józefowicz Sz., 2015, Planktonic Indices in the Evaluation of the Ecological Status and the Trophic State of the Longest Lake in Poland, Ecol. Indicat. 56: 15-22.

Dokulil M., Teubner K., 2000, Cyanobacterial dominance in lakes, Hydrobiologia 438(1): 1-12.

Dokulil M., Teubner K., 2003, Eutrofication and restoration of shallow lakes - the concept of stable equilibria revisted, Hydrobiologia 506(1): 29-35.

Elser J.J., Carpenter S.R., 1988, Predation-driven dynamics of zooplankton and phytoplankton communities in a whole-lake experiment, Oecologia 76(1): 148-154.

Hillebrand H., Dürselen C., Kirschtel D., Pollingher U., Zohary T., 1999, Biovolume calculation for pelagic and benthic microalgae, J. Phycol. 35: 403-424.

Hutchinson G.E. 1967, A treatise on limnology. Vol. 2: Introduction to lake biology and the limnoplankton, John Willey and Sons, New York-London, pp. 1115.

Hutorowicz A., Pasztaleniec A., 2014, Phytoplankton Metric of Ecological Status Assessment for Polish Lakes and its performance along nutrient gradients, Pol. J. Ecol. 62(3): 525-540.

[IMGW] Instytut Meteorologii i Gospodarki Wodnej (Institute of Meteorology and Water Management), 2014, Biuletyn Monitoringu Klimatu Polski. Lipiec 2014 (Monthly Climate Monitoring Bulletin. Julay 2014). Retrieved from http://www.imgw.pl/images/stories/biuletyn_monitoringu/2014/ lipiec2014rok.pdf.

Jańczak J. (ed.), 1996, Atlas jezior Polski. Tom I. Jeziora Pojezierza Wielkopolskiego I Pomorskiego w granicach dorzecza Odry (Atlas of lakes in Poland. Volume I. Lakes of the Greater Poland and Pomeranian Lakelands within the River Oder basin), Wydaw. Nauk. Bogucki, Poznań, p. 268 (in Polish).

Kobos J., Błaszczyk A., Hohlfeld N., Toruńska-Sitarz A., Krakowiak A., Hebel A., Sutryk K., Grabowska M., Toporowska M., Kokociński M., Messyasz B., Rybak A., Napiórkowska-Krzebietke A., Nawrocka L., Pełechata A., Budzyńska A., Zagajewski P., Mazur-Marzec H., 2013, Cyanobacteria and cyanotoxins in Polish freshwater bodies, Oceanol. Hydrobiol. Stud. 42(4): 358-378.

Kovach W.L., 2010, MVSP - A MultiVariate Statistical Package for Windows, ver. 3.2 Kovach Computing Services, Pentraeth, pp. 112.
Kratzer C.R., Brezonik P.L., 1981, A Carlson-type trophic state index for nitrogen in Florida lakes, Water. Res. Bull. 17(4): 713-15.

Kruk C., Mazzeo N., Lacerot G., Reynolds C.S., 2002, Classification schemes for phytoplankton: a local validation of a functional approach to the analysis of species temporal replacement, J. Plankton Res. 24(9): 901-912.

Padisák J., Reynolds C.S., 2003, Shallow lakes: the absolute, the relative, the functional and the pragmatic, Hydrobiologia 506(1): 1-11.

Padisák J., Crossetti L.O., Naselli-Flores L., 2009, Use and misuse in the application of the phytoplankton functional classification: a critical review with updates, Hydrobiologia 621(1): 1-19.

Paerl H.W., Otten T.G., 2013, Harmful cyanobacterial blooms: causes, consequences, and controls, Microb. Ecol. 65(4): 995-1010.

Reynolds C.S., Oliver R.L., Walsby A.E., 1987, Cyanobacterial dominance: the role of buoyancy regulation in dynamic lake environments, New Zeal. J. Mar. Freshwat. Res. 21: 379-90.

Reynolds C.S., Huszar V., Kruk C., Naselli-Flores L., Melo S., 2002, Towards a functional classification of the freshwater phytoplankton, J. Plankton Res. 24: 417-428.

Reynolds C.S., 2006, The ecology of phytoplankton, Cambridge University Press, Cambridge, pp. 552.

Scheffer M., Jeppesen E., 1998, Alternative stable state, [in:] Jeppesen E., Søndergaard M., Søndergaard M., Christoffersen K. (eds), The structuring role of submerged macrophytes in lakes, Ecological Studies 131, Springer, New York-Berlin-Heidelberg: 397-406.

Smayda T.J.,1997, What is a bloom? A commentary, Limnol. Oceanogr. 42(5/2): 1132-1136.

Sun, J., Liu, D., 2003, Geometric models for calculating cell biovolume and surface area for phytoplankton. J. Plankton Res. 25 (11): 1331-1346.

Utermöhl H., 1958, Zur Vervollkommnung der quantitativen Phytoplankton - Methodik, Mitt. Int. Ver. Theor. Angew. Limnol. 9: 1-38.

Van Dam H., Mertens A., Sinkeldam J., 1994, A coded checklist and ecological indicator values of freshwater diatoms from the Netherlands, Neth. J. Aquat. Ecol. 28(1): 117-133.

Vollenweider R.A. Kerekes J., 1982, Eutrophication of waters. Monitoring, assessment and control, OECD Cooperative programme on monitoring of inland waters (Eutrophication control), Environment Directorate, OECD, Paris, pp. 154.

[WIOŚ] Wojewódzki Inspektorat Ochrony Środowiska w Bydgoszczy (Voivodeship Environmental Protection Inspectorate in Bydgoszcz), 2005, Stan czystości jezior województwa - zestawienia zbiorcze (1993-2006). Jezioro Ostrowąs (State of purity of lakes of the voivodeship collective statements (1993-2006). Lake Ostrowąs). IOŚ -WIOŚ w Bydgoszczy, Bydgoszcz. Retrived from: http:// www.wios.bydgoszcz.pl/webmapa/wody/ostrowas.html 
